\title{
Senna spectabilis FRUIT ON HAIR LAMBS FEEDING: DIGESTIBILITY, BLOOD METABOLITES, AND RUMINAL KINETIC
}

\author{
FARINHA DE FRUTO DE Senna spectabilis NA ALIMENTAÇÃO DE \\ CORDEIROS DESLANADOS: DIGESTIBILIDADE, METABOLITOS \\ SANGUÍNEOS E CINÉTICA RUMINAL
}

\author{
Danilo Bonilla-Trujillo ${ }^{1}$ \\ Jairo Andrés Pardo-Guzman ${ }^{1}$ \\ Román David Castañeda-Serrano ${ }^{*}$ \\ ${ }^{1}$ Universidad del Tolima, Tolima, CO \\ *Corresponding author - rcastaneda@ut.edu.co
}

\begin{abstract}
In recent years sheep, farming has emerged as an alternative production system especially in dry areas. The use of leaves and fruit from some trees has become an alternative for feeding for ruminants; however, studies on these species are scarce. The objective of this study was to evaluate the effect of S. spectabilis fruit meal on in vivo and in vitro digestibility, blood metabolites, and ruminal kinetics in hair lambs. This study was carried out at Las Brisas farm, University of Tolima - Colombia. Twelve male hair lambs with body weight of $20.3 \pm 2.5 \mathrm{~kg}$ were used. Animals were distributed in an experimental $4 \times 4$ Latin square design. The treatments consisted of diets based on Dichanthium spp hay with different inclusion levels of $S$. spectabilis fruit meal (15, 30, and 45\%). A linear increasing effect $(\mathrm{P}<0.05)$ was observed for in vivo and in vitro digestibility of dry matter, organic matter, and crude protein; likewise, plasma urea and ruminal degradability increased as the level of supplementation of $S$. spectabilis increased. The meal of $S$. spectabilis improves digestibility, protein intake, and ruminal kinetics in hair lambs; therefore, it is suggested as a promising alternative for ruminants feeding in dry tropic regions.
\end{abstract}

Keywords: Colombian creole lambs; small ruminants; silvopastoral systems; tropical dry forest.

\section{Resumo}

Nos últimos anos, a criação de ovelhas surgiu como um sistema de produção alternativo, especialmente em áreas secas. $\mathrm{O}$ uso de folhas e frutos de algumas árvores é uma alternativa para a alimentação dos ruminantes; no entanto, os estudos sobre essas espécies são escassos. O objetivo deste estudo foi avaliar o efeito da farinha de $S$. spectabilis na digestibilidade in vivo e in vitro, nos metabolitos sanguíneos e na cinéticos ruminal em ovinos deslanados. este estudo foi realizado na fazenda Las Brisas da Universidade do Tolima - Colômbia. Doze machos com peso corporal de 20,3 \pm 2,5 $\mathrm{kg}$ foram distribuídos num delineamento experimental quadrado Latino 4X4. Os tratamentos consistiram em dietas baseadas em feno de Dichanthium spp com diferentes inclusões de frutos de S. spectabilis (15, 30 e $45 \%)$. Foi observado um efeito linear crescente $(\mathrm{P}<0,05)$ para a digestibilidade in vivo e in vitro da matéria seca, matéria orgânica e proteína bruta; igualmente, para ureia plasmática e 
degradabilidade ruminal, à medida que o nível de suplementação de $S$. spectabilis aumentou. A farinha de $S$. spectabilis melhora a digestibilidade, o consumo de proteína e a cinética ruminal em cordeiros deslanados; portanto, pode ser sugerida como uma alternativa promissora para a alimentação de ruminantes nas regiões do trópico seco.

Palavras-chave: floresta seca tropical; ovelha crioula colombiana; pequenos ruminantes; sistemas silvopastoris.

Received on: October 20th, 2017.

Accepted on: June 20th, 2018.

\section{Introduction}

In recent years, sheep farming has played an important role as an alternative production system in the dry areas of the tropics. However, in these regions ruminants meet their nutritional requirements with native grassland, which contain low protein concentration and high percentages of indigestible fiber (1). Meanwhile, small producers have limited access to raw materials that can be used as supplementation for grazing animals due to the high cost they represent.

Nevertheless, in these ecosystems there is an abundant biodiversity of arboreal and shrub species that have adapted for thousands of years to the extreme conditions of tropical dry forests (high temperatures and low rainfall). Several authors have shown that supplementation with leaves or fruit of tropical tree species improves the productive performance, intake, digestibility, and fermentation parameters in small ruminants diets ${ }^{(2,3)}$. Species such as Leucaena leucocephala, Gliricidia sepium, Tihonia diversifolia, and Moringa oleifera have already demonstrated that they can supplement and improve animal's nutritional status.

Senna spectabilis, commonly known in Colombia as vainillo, is an ornamental fabaceae that derives its name from the Latin spectabilis, which means spectacular ${ }^{(4)}$. Currently, the vainillo has been studied especially for its leaves and flowers alkaloid content ${ }^{(5-7)}$. Alvear et al. ${ }^{(8)}$ determined the bromatological composition of the fruit, observing dry matter, crude protein, and crude energy values of $74.9 \%, 11.3 \%$, and $3.82 \mathrm{Mcal} / \mathrm{kg} \mathrm{DM}$, respectively. Diaz et al. ${ }^{(9)}$, feeding hair sheep supplemented with rice meal and tree species, observed similar weight gains between Senna spectabilis fruit meal and Guazuma ulmifolia and Gliricidia sepium foliage supplementations. Therefore, the objective of this study was to evaluate the effect of levels of Senna spectabilis fruit meal on the in vivo and in vitro digestibility, blood metabolites, and ruminal degradation kinetics in Colombian hair lambs.

\section{Materials and Methods}

The study was carried out at the Research Center of the University of Tolima, Colombia, at $4^{\circ} 25^{\prime} 38.4^{\prime \prime}$ $\mathrm{N}+75^{\circ} 13^{\prime} 40.8^{\prime \prime} \mathrm{W}$, which has an altitude of 1,285 masl, average temperature of $23.1{ }^{\circ} \mathrm{C}$, and precipitation between 1,500 and 2,000 $\mathrm{mm}$. 
In this study, twelve male Colombian creole lambs, nearly to six months of age and body weight near $20,3 \pm 2.5 \mathrm{~kg}$ were used and distributed into treatments, in a 4X4 Latin Square design, in four experimental periods, three animals per experimental unit. The treatments consisted of Angleton hay (Dichanthium spp) diets with different inclusions of Vanillo fruit meal (Senna spectabilis) as follows: T1: 100\% Dichanthium spp hay; T2: 85\% Dichanthium spp hay, 15\% S. spectabilis fruit meal; T3: 70\% Dichanthium spp hay, 30\% S. spectabilis fruit meal; T4: 55\% Dichanthium spp hay, 45\% S. spectabilis fruit meal.

The method used to determine in vivo digestibility of the diet was the total collection of feces (TCF), by means of the implementation of metabolic cages ( $1 \mathrm{~m}$ height $\mathrm{x} 1 \mathrm{~m}$ width $\mathrm{x} 1.5 \mathrm{~m}$ length), equipped with collectors, separators of feces and urine, and individual feeders and drinkers. The animals were submitted to a diet adaptation period of 15 days. they were distributed into different pens for each treatment where the ration was given to each group, taking into account a $4 \%$ dry matter intake per animal according to their live weight, which was adjusted to obtain between 5-10\% rejections. After diet adaptation, the animals were taken to their respective cages where they remained for four days, when gr/day of food consumed, food rejected, excreta and urine production were measured. The apparent digestibility coefficient (ADC) was estimated from the equation: ADC $(\%)=[$ (nutrient consumed gr - nutrient excreted gr) / (nutrient consumed gr)] x 100.

The bromatological composition of the evaluated diets (Table 1) and feces was determined by a proximal chemical analysis according to the methods established by the $\mathrm{AOAC}^{(10)}$ for dry matter content, organic matter, crude protein, ethereal extract, and ash; neutral and acid detergent were assessed according to Van Soest et al. ${ }^{(11)}$.

Dry matter intake of each treatment was calculated during collection days, taking the weight of feed supplied in dry matter to each of the animals at time 0 and the dry matter orts obtained 24 hours later. That intake was expressed in grams per animal per day (g/d-1), DM ingestion (\%) in relation to body weight (DMI\% BW) and DM intake in relation to metabolic weight $\left(\mathrm{kg} \mathrm{W}^{0.75}\right)$.

Table 1. Chemical composition of ingredients and experimental diets as \% DM

\begin{tabular}{lcccccc}
\hline \multirow{2}{*}{$\%$} & \multirow{2}{*}{ Dichanthium spp. } & \multirow{2}{*}{ S. spectabilis } & \multicolumn{5}{c}{ Treatments } \\
\cline { 4 - 7 } & & 90.99 & 90.41 & 90.49 & 90.58 & 90.67 \\
\hline DM & 90.41 & 94.00 & 91.65 & 92.00 & 92.36 & 92.71 \\
OM & 91.65 & 13.50 & 3.18 & 4.73 & 6.28 & 7.82 \\
CP & 3.18 & 46.18 & 78.43 & 73.59 & 68.76 & 63.92 \\
NDF & 78.43 & 29.20 & 39.27 & 37.76 & 36.25 & 34.74 \\
ADF & 39.27 & 0.51 & 1.02 & 0.94 & 0.86 & 0.79 \\
EE & 1.02 & 5.99 & 8.34 & 7.99 & 7.63 & 7.28 \\
ASH & 8.34 & &
\end{tabular}

DM: dry matter; OM: organic matter; CP: crude protein; NDF: neutral detergent fiber; ADF: acid detergent fiber; EE: ethereal extract.

1: Hay Dichanthium spp

2: $85 \%$ Hay Dichanthium spp, S. spectabilis $15 \%$ fruit meal

3: $70 \%$ Hay Dichanthium spp, S. spectabilis 30\% fruit meal

4: $55 \%$ Hay Dichanthium spp, S. spectabilis $45 \%$ fruit meal 
The determination of in vitro DM digestibility for the different treatments was performed using the technique described by Tilley \& Terry ${ }^{(12)}$ adapted to the artificial rumen (DAISY II) developed by $\mathrm{ANKOM}^{\circledR}$. Rumen liquor was collected from a ruminally-cannulated steer $( \pm 350 \mathrm{~kg} \mathrm{BW}) 2 \mathrm{~h}$ after morning feeding, which was maintained in a Cynodon spp pasture. A 0.5-g sample from each diet was weighted, grinded to $1 \mathrm{~mm}$ and placed in F57 ANKOM ${ }^{\circledR}$ filter bags.

These bags were then placed into jars to which the buffer solutions A (10 g of KH2PO4, $0.5 \mathrm{~g}$ of $\mathrm{MgSO}_{4} \cdot 7 \mathrm{H}_{2} \mathrm{O}, 0.5 \mathrm{~g}$ of NaCl, $0.1 \mathrm{~g}$ of $\mathrm{CaCl} 2 \cdot \mathrm{H}_{2} \mathrm{O}$, and $0.5 \mathrm{~g}$ of urea in $1 \mathrm{~L}$ of deionized water) and $\mathrm{B}$ ( $15 \mathrm{~g}$ of $\mathrm{Na}_{2} \mathrm{CO}_{3}$ and $1 \mathrm{~g}$ of $\mathrm{Na}_{2} \mathrm{~S} \mathrm{H}_{2} \mathrm{O}$ in $100 \mathrm{ml}$ of deionized water) were added, in addition to the ruminal inoculum. After that, they were introduced into the DAISY II incubator for $48 \mathrm{~h}$, guaranteeing a temperature of $39^{\circ} \mathrm{C}$. At the end of this period, $40 \mathrm{~mL}$ of $6 \mathrm{~N} \mathrm{HCl}$ and $8 \mathrm{~g}$ of pepsin (EC 3.4.23.1 Sigma ${ }^{\circledR}$ ) were added, and the samples were left for another 24 hours in the incubator. After this time, the bags were dried at $105^{\circ} \mathrm{C}$ for $8 \mathrm{~h}$. In vitro digestibility of DM (IVDDM) was calculated by the difference between the food incubated and the residue after incubation.

The degradation kinetics of DM was determined in parallel with IVDDM using DAISY II ${ }^{\circledR}$. As incubation time for each diet, the hours 3, 6, 12, 18, 36, 48, 72 and 96 was taken into account. The parameters of in vitro rumen degradation of DM were calculated using the equation described by Orskov \& McDonald ${ }^{(13)}: \mathrm{p}=\mathrm{a}+\mathrm{b}\left(1-\mathrm{e}^{\wedge}(-\mathrm{ct})\right)$; in which: $\mathrm{p}=$ rate of degradation at time $\mathrm{t}$; $\mathrm{a}=$ water soluble fraction; $b=$ fraction of insoluble, potentially degradable water; $c=$ rate of degradation of fraction $b ; t=$ incubation time. The effective degradability (ED) of the DM was calculated using the following equation: $\mathrm{ED}=\mathrm{a}+(\mathrm{b} \times \mathrm{c} / \mathrm{c}+\mathrm{k})$; where $\mathrm{k}$ is the velocity of the passage of particles in the rumen. The effective degradability of in vitro DM was estimated for each diet, considering the passage rates of 2,5 , and $8 \% / \mathrm{h}$, values that can be attributed to low, medium, and high consumption levels, respectively. Potential degradability was calculated using the following equation: $P D=a+b$.

The determination of glucose, blood urea nitrogen (BUN) and $\beta$-hydroxybutyrate was performed for each animal at the end of each collection period. A venipuncture was performed in the jugular vein using Vacutainer ${ }^{\mathrm{TM}}$. Samples were refrigerated and then analyzed using commercial Biosystems ${ }^{\circledR}$ (glucose and BUN) and Randox ${ }^{\circledR}(\beta$-hydroxybutyrate) kits and the Biosystems $A 15 \AA$ automatic blood chemistry system at the Laboratory of Veterinary Diagnostics at the University of TolimaLADIVE.

The results obtained were interpreted by analysis of variance and regression study, using orthogonal polynomials. In vitro ruminal degradation parameters were estimated using the Gauss-Newton interactive process by means of the procedure for non-linear models (PROC NLIN) of the SAS program (Statistical Analysis System, version 9.1). All statistical procedures were evaluated using the PROC REG procedure of the SAS statistical program (Statistical Analysis System, version 9.1).

The experiment was developed taking into account the bioethical regulations for animal experimentation contemplated by the University of Tolima (academic council agreement number 0171 from October 29, 2017) and act number 02 of 2017 of the committee of bioethics. 


\section{Results}

No differences were observed between the treatments $(\mathrm{P}>0.05)$ for the $\mathrm{DM}$ and OM intake with the inclusion of different levels of $S$. spectabilis to the diets. However, a lower intake of NDF and higher $\mathrm{CP}$ intake was observed for the treatments with greater inclusion of $S$. spectabilis. Furthermore, as the protein value of the evaluated diets was increased (Table 1), a proportional increase in CP intake and digestibility was generated. These effects can be seen in linear and quadratic ways for the two variables (Table 2).

Table 2. Intake (INT), feces excretion (FE), and digestibility (Dig) of dry matter (DM), organic matter (OM), neutral detergent fiber (NDF), and crude protein (CP) in hair lambs fed different levels of $S$. spectabilis fruit meal

\begin{tabular}{|c|c|c|c|c|c|c|c|c|}
\hline \multicolumn{2}{|c|}{ Variables } & \multicolumn{4}{|c|}{ Treatments } & \multirow{2}{*}{$\mathbf{E E}^{5}$} & \multicolumn{2}{|c|}{ P value } \\
\hline & & 1 & 2 & 3 & 4 & & $\mathbf{L}$ & $\mathbf{Q}$ \\
\hline \multirow{5}{*}{$\mathrm{DM}$} & $\mathrm{INT} g / \mathrm{d}$ & 529.56 & 545.19 & 547.50 & 524.56 & 5.85 & 0.875 & 0.555 \\
\hline & INT \% BW & 2.52 & 2.64 & 2.73 & 2.64 & 0.05 & 0.337 & 0.381 \\
\hline & $\mathrm{INT}^{0.25 \mathrm{BW}}$ & 5.40 & 5.62 & 5.81 & 5.57 & 0.09 & 0.413 & 0.348 \\
\hline & $\mathrm{FE} \mathrm{g} / \mathrm{d}$ & 261.91 & 267.58 & 239.15 & 222.73 & 0.61 & 0.012 & 0.030 \\
\hline & Dig, $\%$ & 50.29 & 50.61 & 56.01 & 57.64 & 0.92 & 0.0005 & 0.002 \\
\hline \multirow{3}{*}{$\mathrm{OM}$} & INT, $g / d$ & 492.83 & 508.49 & 513.01 & 491.92 & 8.14 & 0.980 & 0.539 \\
\hline & $\mathrm{FE} \mathrm{g} / \mathrm{d}$ & 222.63 & 228.07 & 205.73 & 195.09 & 5.83 & 0.043 & 0.103 \\
\hline & Dig,\% & 54.64 & 54.86 & 59.60 & 61.49 & 0.87 & 0.001 & 0.001 \\
\hline \multirow{3}{*}{ NDF } & INT, $g / d^{-1}$ & 411.87 & 396.40 & 379.45 & 342.07 & 5.90 & $<0.0001$ & $<0.0001$ \\
\hline & $\mathrm{FE} \mathrm{g} / \mathrm{d}$ & 201.55 & 191.62 & 169.49 & 170.21 & 5.43 & 0.015 & 0.000 \\
\hline & Dig,\% & 50.86 & 51.52 & 54.91 & 52.36 & 0.94 & 0.342 & 0.477 \\
\hline \multirow{3}{*}{$\mathrm{CP}$} & INT, g/d & 19.68 & 30.40 & 35.19 & 37.47 & 1.29 & $<0.0001$ & $<0.0001$ \\
\hline & $\mathrm{FE} g / \mathrm{d}$ & 10.95 & 13.13 & 14.22 & 12.61 & 0.38 & 0.077 & 0.007 \\
\hline & Dig, $\%$ & 44.36 & 56.80 & 58.39 & 65.94 & 1.69 & $<0.0001$ & $<0.0001$ \\
\hline
\end{tabular}

1: Hay Dichanthium spp

2: $85 \%$ Hay Dichanthium spp, S. spectabilis $15 \%$ fruit meal

3: $70 \%$ Hay Dichanthium spp, S. spectabilis $30 \%$ fruit meal

4: $55 \%$ Hay Dichanthium spp, S. spectabilis $45 \%$ fruit meal

${ }^{5}$ EEM: standard error of the mean

For nutrients digestibility, as the percentage of inclusion of $S$. spectabilis to the diets increased, the digestibility of DM, OM, and CP $(\mathrm{P}<0.05)$ improved. However, the digestibility of NDF was similar among the treatments $(\mathrm{P}>0.05)$.

The values of BUN (mg / dL) increased as the supplementation level of $S$. spectabilis fruit meal (P $<0.05)$ was increased. Values ranged from 10.66 to $17.54 \mathrm{mg}$ dL for treatments $0 \%$ and $45 \% S$. spectabilis fruit meal (Table 3 ). On the other hand, serum glucose concentration did not vary among 
the treatments $(\mathrm{P}>0.05)$, presenting values ranging from 49.54 to $50.36 \mathrm{mg} / \mathrm{dL}$.

The "a" fraction in the different diets presented a linear increase as the inclusion levels of $S$. spectabilis fruit meal increased from $15.16 \%$ to $27.23 \%$. Meanwhile, the "b" fraction presented an inverse relation, as the inclusion levels of $S$. spectabilis fruit meal decreased this parameter that also directly influenced the potential degradability (PD), indicating that the greater inclusion level of this fruit decreases the time determined for ruminal degradation (Table 4).

Table 3. Blood metabolites in hair lambs fed different levels of S. spectabilis fruit meal

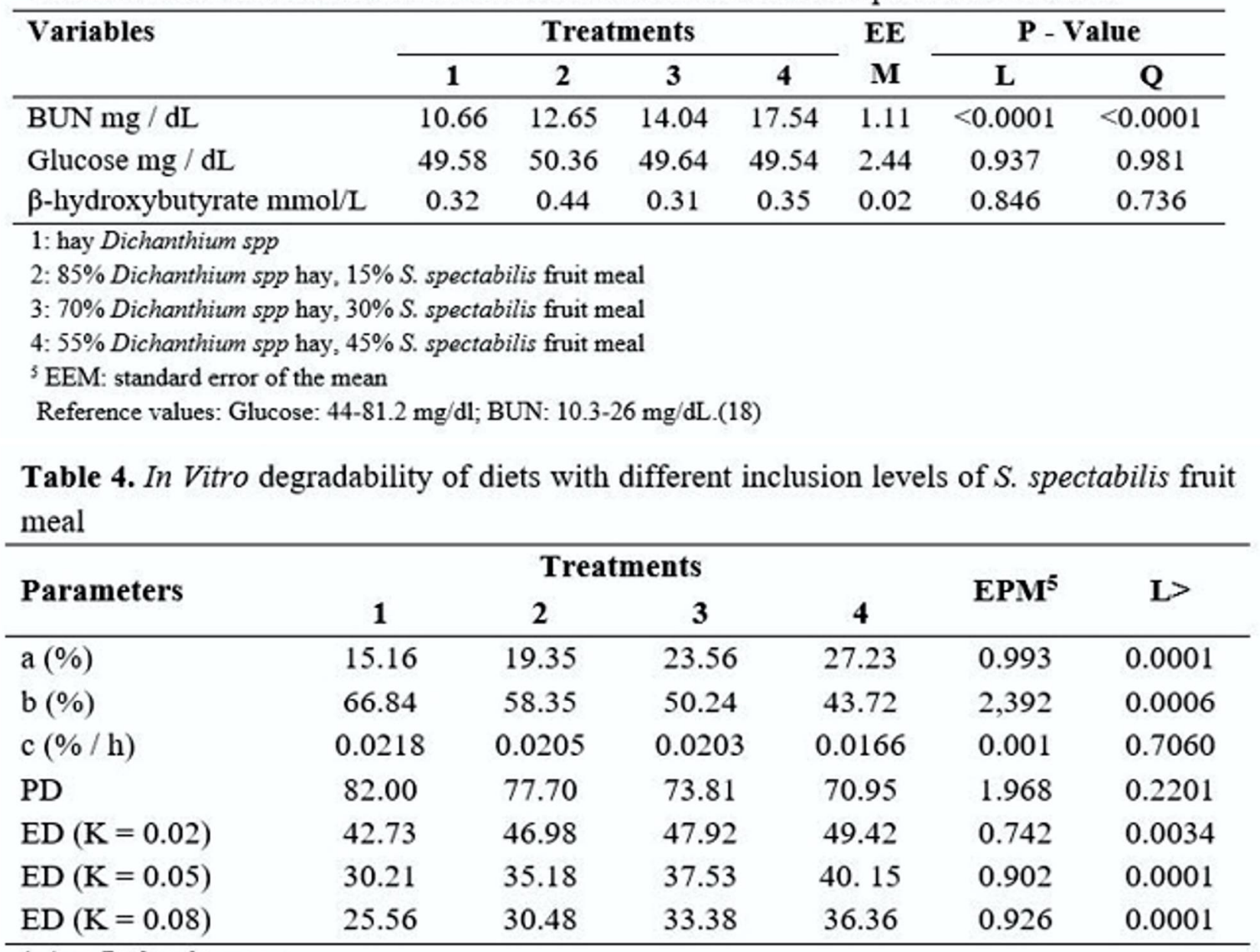

1: hay Dichanthium spp

2: $85 \%$ Dichanthium spp hay, $15 \%$ S. spectabilis fruit meal

3: $70 \%$ Dichanthium spp hay, $30 \%$ S. spectabilis fruit meal

4: $55 \%$ Dichanthium spp hay, $45 \%$ S. spectabilis fruit meal

${ }^{5} \mathrm{EEM}$ : standard error of the mean.

$a(\%)=$ water soluble fraction; $b(\%)=$ fraction insoluble in water, but potentially degradable; $c(\% / h)=$ rate of degradation fraction $\mathrm{a} ; \mathrm{PD}=$ potential degradation; $\mathrm{ED}=$ effective degradation.

On the other hand, the effective degradability evaluated with $\mathrm{K}$ values $(0.02,0.05$, and 0.08$)$ had a linear behavior as the inclusion levels of $S$. spectabilis fruit meal increased. Table 5 shows a linear and quadratic effect for the degradability of the different diets evaluated, from hour 3 to hour 48 $(<0.0001)$. However, this effect was not observed from hour 60 . 
Table 5. In vitro degradability in hours and in vitro digestibility of dry matter in diets with different inclusion levels of $S$. spectabilis fruit meal

\begin{tabular}{lccccccc}
\hline \multirow{2}{*}{ Degradability\% / hour } & \multicolumn{4}{c}{ Treatments } & \multirow{2}{*}{ EEM $^{5}$} & \multicolumn{2}{c}{ P value } \\
\cline { 2 - 5 } & $\mathbf{1}$ & $\mathbf{2}$ & $\mathbf{3}$ & $\mathbf{4}$ & & $\mathbf{L}$ & $\mathbf{Q}$ \\
\hline 3 & 17.36 & 21.15 & 24.95 & 28.74 & 0.06 & $<0.0001$ & $<0.0001$ \\
6 & 20.58 & 24.20 & 27.81 & 31.43 & 0.09 & $<0.0001$ & $<0.0001$ \\
12 & 26.23 & 30.88 & 34.19 & 37.50 & 0.95 & $<0.0001$ & $<0.0001$ \\
24 & 36.31 & 39.62 & 42.94 & 46.26 & 0.64 & $<0.0001$ & $<0.0001$ \\
36 & 38.38 & 41.26 & 47.20 & 49.65 & 1.36 & $<0.0001$ & $<0.0001$ \\
48 & 47.50 & 49.18 & 50.87 & 52.56 & 0.61 & $<0.0001$ & $<0.0001$ \\
60 & 54.11 & 53.39 & 55.8 & 56.53 & 1.49 & 0.149 & 0.320 \\
72 & 55.68 & 56.38 & 57.09 & 57.09 & 0.54 & 0.005 & 0.023 \\
84 & 62.70 & 62.9 & 63.1 & 63.30 & 0.3 & 0.129 & 0.325 \\
96 & 64.35 & 64.38 & 64.41 & 64.44 & 0.24 & 0.765 & 0.957 \\
In vitro digestibility\% & 52.94 & 54.71 & 56.49 & 58.26 & 0.433 & $<0.0001$ & $<0.0001$ \\
\hline
\end{tabular}

1: hay Dichanthium spp

2: $85 \%$ Dichanthium spp hay, $15 \%$ S. spectabilis fruit meal

3: $70 \%$ Dichanthium spp hay, $30 \%$ S. spectabilis fruit meal

4: $55 \%$ Dichanthium spp hay, $45 \%$ S. spectabilis fruit meal

${ }^{5} \mathrm{EEM}$ : standard error of the mean

\section{Discussion}

The effects on nutrients digestibility can be explained by the better bromatological composition of $S$. spectabilis fruit meal, regarding especially NDF contents in the evaluated diets (Table 1). T1 (Dichanthium spp hay) and T2 (Hay and 15\% fruit meal) treatments had higher NDF content in relation to T3 (Hay and 30\% fruit meal) and T4 (Hay and 45\% fruit meal). High levels of NDF and ADF decrease the passage, degradation and digestibility rates due to the difficult access of this component to rumen microorganisms. Gebremariam et al. ${ }^{(14)}$ reported similar effects to those observed in the present study when evaluating inclusion levels of Opuntia ficus-indica. The authors observed that the higher the NDF content in the diet, the lower the digestibility coefficient. Similarly, Reyes et al. ${ }^{(15)}$ observed that digestibility is influenced by the contents of NDF and ADF; however, this can be improved as they are included within the diets ingredients with higher levels of nonfibrous carbohydrates as it is the case of $S$. spectabilis fruit meal in the present study.

The results on intake and digestibility support the results presented by Diaz et al. ${ }^{(9)}$, who supplemented hair lambs with $0.5 \%$ dry matter BW from different alternative sources and observed that the animals fed $S$. spectabilis fruit meal gained between 81 and $85 \%$ more weight than animals that were not supplemented. Therefore, it can be inferred that the fruits of $S$. spectabilis can become an interesting alternative to supplement sheep in tropical dry forest systems, where the availability of grains and byproducts of agroindustry is scarce and expensive.

On the other hand, the improvement in the intake and digestibility in the diets with greater Vainillo 
inclusion can be explained by the quality and quantity of protein present in the diets since protein of the grasses has a greater amount of less soluble fractions ${ }^{(16)}$. Kholif et al. ${ }^{(17)}$ found similar results for the inclusion of Moringa oleifera at the levels of 100,150 and $200 \mathrm{~g} / \mathrm{kg}$. The authors verified that the increase in the legume proportion in the diet improved the protein offer to the animal and this was reflected in a linear effect on DM intake and digestibility.

Regarding BUN, it is evident that, as the inclusion level of $S$. spectabilis to the diets increased, the protein intake improved, which was reflected in higher levels of this metabolite in the blood. However, in the treatment without $S$. spectabilis fruit meal (T1), the values tended to the minimum limit according to the clinical parameters reported by Tschuor et al. ${ }^{(18)}$. The higher levels of BUN may reflect a better contribution of nitrogen to the synthesis of microbial protein, but may also reflect the poor energetic contribution of the pasture, as demonstrated by its bromatological composition.

Nevertheless, the better energetic contribution of the diets with greater inclusion of $S$. spectabilis fruit meal was not reflected in changes in glucose concentrations nor $\beta$-hydroxybutyrate. In all treatments, glucose and $\beta$-hydroxybutyrate were maintained in the lower limit according to Panousis et al. ${ }^{(19)}$, who describe normal values of 50 to $80 \mathrm{mg} / \mathrm{dL}$.

According to Przemysław et al. ${ }^{(20)}$, glucose concentrations are closely correlated with dry matter and energy intake, suggesting that energy consumption in all treatments was adjusted to meet animal's maintenance requirements. This hypothesis is supported by the consumption data in Table 3 , where in no treatment the DMI reached $3 \%$ of the BW. However, Russel et al. ${ }^{(21)}$ stated that $\beta$ hydroxybutyrate values are closely related to the level of fat mobilization and a deficit in the animal's energy balance. The results of the present study showed no changes in this parameter; thus, it can be inferred that the animals were not in negative energy balance.

Similarly, Lotfollahzadeh et al. ${ }^{(22)}$ reported that, in animals with energy deficit, an increase in $\beta$ hydroxybutyrate concentrations is expected. However, although the diets of the current study were based on low quality forage with NDF and CP values of $78 \%$ and $3.1 \%$, respectively, the animals showed no alterations in glucose and $\beta$-hydroxybutyrate. Higher quality diets produce higher levels of blood glucose, such as by substituting dry rolled maize and soybean cake for different inclusion levels of Jatropha curcas fruit in diets for hair sheep, X observed glucose values between 81.8 and $83.8 \mathrm{mg} / \mathrm{dL}$. However, $80 \%$ of concentrate in the diets, whereas in this study only S. spectabilis fruit meal was used as source of supplementation at the levels of 15 to $45 \%$ of the diet. Likewise, Peng et al. ${ }^{(23)}$, evaluating the effect of substitution of alfalfa hay by purple clover on Canadian Arcoot sheep, showed glucose values between 74 and $84 \mathrm{mg} / \mathrm{dL}$, which are much higher than the values reported in this study.

The "a" fraction represents the soluble portion of the diet. Senna spectabilis fruit meal increased this parameter considerably from 15 to $27 \%$ in treatments T1 (Dichanthium spp hay) and T4 (hay and $45 \%$ fruit meal), respectively. These results agree with DM degradability in "a" fraction reported by Gonzalez et al. ${ }^{(24)}$, who evaluated the degradability of by-products used in sheep diets, observing "a" fraction values of 22.06, 21.34, and $20.77 \%$ for soybean meal, corn gluten, and wheat bran, respectively. These results are also in agreement with those reported by Assefa et al. ${ }^{(25)}$, who replaced diets with Chamaecytisus palmensis concentrate for sheep and observed that this forage had higher "a" fraction contents, which directly influenced the degradability of the diets. Other results similar to the ones found in this study were reported by La et al. ${ }^{(26)}$, who evaluated the effect of the combination 
of Tithonia diversifolia and Pennisetum Purpureum vc. Cuba CT-115 in the kinetics and production of gas, in vitro, under different combinations, observing that as the inclusion of $T$. divesifolia increased, the "a" fraction also increased, and hence the degradability. This is the reason why the inclusion of some species of both fruit and leaf trees become an interesting option for the dry tropics.

Regarding the effective degradability, the response observed in the present study can be explained by the smaller amount of fiber contained in diets including $S$. spectabilis fruit meal, which generates a higher passage rate due to the greater degradability in the rumen ${ }^{(27)}$. Valdivia $\& \mathrm{Ku}$ Vera $^{(28)}$ evaluated the kinetics of solid and liquid digesta in Pelibuey sheep fed increasing levels of B. alicastrum incorporated into a low quality guinea grass (Panicum Maximum). These authors observed that the greater inclusion of this shrub species significantly improved the effective degradability of the total diet due to the type of carbohydrates present in this plant, similarly to the response obtained in this study. The degradability over time of the different diets evaluated are in accordance with the results shown above and are in agreement with the reports of several researchers. Resendiz et al. ${ }^{(29)}$ evaluated different levels of alfalfa (Medicago sativa L.) in the diet of lambs. They observed that by increasing the levels of alfalfa decreased DM degradability, explaining the decrease in dietary fiber increase and the lignin content contributed by the alfalfa since it next to the cellulose form a barrier protecting DM from microorganisms attack. Phillips et al. ${ }^{(30)}$ evaluated levels of alfalfa and kenaf (Hibiscus cannabinus) pelleted for lambs and reported that increasing alfalfa levels in the pellet, decreasing the kenaf digestibility which attributable to lower digestibility of the NDF and higher alfalfa content, compared to that of kenaf. The behavior shown in the results of the present study can be explained by the greater effective degradability (Table 4) of the diets with higher inclusion of S. spectabilis fruit meal, which present a greater degradation and passage rate in the first hours (Table 5). However, from the 48th hour, the degradation does not present any difference because S. spectabilis fruit meal disappears from the ruminal environment almost in its entirety, while the grass remains for a longer time in the rumen.

\section{Conclusions}

It can be inferred that, under grazing conditions with grasses of low nutritional quality, using Senna spectabilis fruit meal as the only source supplementation for sheep is not sufficient to meet the energetic and protein requirements of the animals. On the other hand, the parameters of ruminal degradation and digestibility of diets improve as the supplementation of S. spectabilis increases. We suggest that more studies with isoproteic and isoenergetic diets in which energy conventional feeds are replaced by Senna spectabilis fruit meal should be carried out. Finally, we propose the Senna spectabilis fruit meal as a promising alternative for the supplementation of ruminants in tropical regions of the world.

\section{References}

1. Tikam K, Phatsara C, Sorachakula C, Vearasilp T, Samiprem S, Cherdthong A. (et al). In vitro gas production, in vivo nutrient digestibilities, and metabolisable energy concentrations for sheep of fresh and conserved pangola grass. I believe it is Small Ruminant Res. 2015; 128: 34-40. 
2. Rao B. V, Parthasarathy M, Krishna N. Effect of supplementation with tree leaves on intake and digestibility of hybrid napier (NB-21) grass in Nellore Brown sheep. Anim. Feed Sci. Technol. 1993; 44: 265-274.

3. Ephrem N, Tegegne F, Mekuriaw Y, Yeheyis L. Nutrient intake, digestibility and growth performance of Washera lambs supplemented with graded levels of sweet blue lupin (Lupinus angustifolius). Small Ruminant Res. 2015; 130:105-107.

4. Monkheang P, Sudmoon R, Tanee T, Noikotr K, Bletter N, et al. Species diversity, usages, molecular markers and barcode of medicinal Senna species ( Fabaceae, Caesalpinioideae ) in Thailand. JMPR. 2011; 5(26): 6173-6181.

5. De Albuquerque M, Silva M, Guimarães P, Pinheiro M, Matta C, De Queiroz, et al. Leishmanicidal activity of the crude extract, fractions and major piperidine alkaloids from the flowers of Senna spectabilis. Phytomedicine. 2014; 21(3): 277-281.

6. Pereira R, Ferreira G, Pivatto M, De Ávila L, Da Silva B, De Paula D, et al. Alkaloids derived from flowers of Senna spectabilis, (-)-cassine and (-)-spectaline, have antiproliferative activity on HepG2 cells for inducing cell cycle arrest in G1/S transition through ERK inactivation and downregulation of cyclin D1 expression. Tox. in Vitro 2016; 31: 86-92.

7. De Castro A, Castro A, Silva M, De Souza I, Martins-Souza R, Chagas-Paula D, et al. In vitro evaluation of the schistosomicidal effect of the extracts, fractions and major 3-hydroxy-2, 6-dialkyl-substituted piperidine alkaloids from the flowers of Senna spectabilis (Fabaceae). Bioorg. \& med. Chem. 2016; 26(17): 4197-4204.

8. Alvear C, Melo W, Apráez J, Gálvez A, Insuasty, E. Especies arbóreas y arbustivas con potencial silvopastoril en la zona de bosque muy seco tropical del norte de Nariño y sur del Cauca. Agrofo. Neo 2013; 3: $37-46$

9. Díaz V, Duarte J, Castañeda R. Desempeño animal de ovinos de pelo colombianos, suplementados con especies arbóreas del bosque seco tropical. Rev Col Cien Anim. 2013; 7: 82-88

10. AOAC, Official methods of analysis, 2000; 17th ed. Virginia.

11. Van soest P, Robertson J, Lewis B, Methods for Dietary Fiber, Neutral Detergent Fiber, and Nonstarch Polysaccharides in Relation to Animal Nutrition. J. Dairy Sci. 1991; 74: 3583-3597.

12. Tilley J, Terry R. Two-stage technique for the In vitro digestion of forage crops. J. Br. Grass. Soc. 1963; 18: $104-111$

13. Orskov E, McDonald I. The estimation of protein degradability in the rumen from incubation measurements weighted according to rate of passage. J Agric Sci 1979; 92(2): 492-503.

14. Gebremariam T, Melaku S, Yami A. Effect of different levels of cactus (Opuntia ficus-indica) inclusion on feed intake, digestibility and body weight gain in tef (Eragrostis tef) straw-based feeding of sheep. Anim feed sci tech 2006; 131: 42-51.

15. Reyes N, Spörndly E, Ledin I. Effect of feeding different levels of foliage of Moringa oleifera to creole dairy cows on intake, digestibility, milk production and composition. Lives. Sci 2006; 101:24-31.

16. Alzueta C, Caballero R, Rebolé A, Treviño J, Gil A, Rebole A, et al. Crude protein fractions in common vetch (Vicia sativa $L$ ) fresh forage during pod filling. J. Anim. Sci. 2001; 79: 2449-2455.

17. Kholif A, Gouda G, Morsy A, Salem A, Lopez S, Kholif A M. Moringa oleifera leaf meal as a protein source in lactating goat's diets: Feed intake, digestibility, ruminal fermentation, milk yield and composition, and its fatty acids profile. Small Ruminant Res. 2015; 129: 129-37

18. Tschuor A, Riond B, Braun U, Lutz H. Hämatologische und klinisch-chemische Referenzwerte für adulte Ziegen und Schafe. Schweizer Archiv Für Tierheilkunde. 2008; 287-295. 
19. Panousis N, Brozos C, Karagiannis I, Giadinis N, Lafi S, \& Kritsepi-konstantinou M. Research in Veterinary Science Evaluation of Precision Xceed Ò meter for on-site monitoring of blood b -hydroxybutyric acid and glucose concentrations in dairy sheep. Research in Veterinary Science 2012; 93(1): 435-439.

20. Przemysław S, Cezary P, Stanisław M, Katarzyna Z. The effect of nutritional and fermentational characteristics of grass and legume silages on feed intake, growth performance and blood indices of lambs. Small Ruminant Res 2015; 123:1-7

21. Russel A J, Doney J M, Reid R L. The use of biochemical parameters in controlling nutritional state in pregnant ewes, and the effect of undernourishment during pregnancy on lamb birth-weight. J. of Agric. Sci. 1967; 68(3): 351-358.

22. Lotfollahzadeh S, Zakian A, Tehrani-Sharif M, Watson D. Assessment the alterations of some biochemical parameters in Afshari sheep with possible metabolic disorders. Small Ruminant Res 2016; 145: 58-64.

23. Peng K, Shirley D, Xu Z, Huang Q, Tim A, Chaves A, et al.. Effect of purple prairie clover (Dalea purpurea Vent.) hay and its condensed tannins on growth performance, wool growth, nutrient digestibility, blood metabolites and ruminal fermentation in lambs fed total mixed rations. Anim. Feed Sci. Technol. 2016; 222: $100-110$.

24. González H, Lozano G, Hernández H, Orozco A, Holguín L. Degradabilidad ruminal de subproductos alimenticios en borregos. Efecto de la relación forraje-concentrado en la dieta. Colección Reportes Técnicos de Investigación 2015; ISBN: 978-607-7953-80-7 Serie ICB, Vol. 16. ISBN: 978-607-520-148-1

25. Assefa G, Kijora C, Kehaliew A, Bediye S, Peters K. Evaluation of tagasaste (Chamaecytisus palmensis ) forage as a substitute for concentrate in diets of sheep. Liv. Sci. 2008; 114: 296-304.

26. La O, Valenciaga D, González H, Orozco A, Castillo Y, Ruíz O, et al. Purpureum vc . Cuba CT-115 en la cinética y producción de gas in vitro. Rev. Cuba. Cienc. Agric. 2009; 43: 149-152.

27. Orskov E, Mould F. Manipulation of rumen fluid $\mathrm{pH}$ and its influence on cellulolysis in sacco, dry matter degradation and the rumen microflora of sheep offered either hay or concentrate. Anim. Feed Sci. Technol 1983; 10: 1-14.

28. Valdivia V, Ku Vera J. Efecto del ramón (Brosimum alicastrum) sobre la digestión ruminal y el flujo de proteína microbiana en ovinos Pelibuey alimentados con pasto guinea (Panicum maximum). Reun. Nac. Investig. Pecu. 1996

29. Resendiz C, Hernández O, Guerrero I, Gallegos J, Martínez, P, Sánchez C. Engorda de corderos Pelibuey con diferente nivel de alfalfa en la dieta. Arch. Zootec. 2013; 62: 457-467.

30. Phillips W, Rao S, Fitch J, Mayeux H. Digestilility and dry matter intake of diets containing alfalfa and kenaf. J Anim Sci 2002; 80: 2989-2995 